\title{
Village Funds Mismanagement in Policy Evaluation Perspective in Jejangkit Pasar Village of South Kalimantan
}

\author{
Taufik Arbain, Erma Ariyani \\ Faculty of Social and Political Sciences University of Lambung Mangkurat \\ (email: datuktaufikarbain@gmail.com)
}

\begin{abstract}
The village fund policy is implemented to improve infrastructure development, community development and empowerment towards a prosperous village. However, the management of village funds did not meet expectations, due to lack of community participation in supervision. The purpose of this study is to analyze the mismanagement of village funds using a policy evaluation perspective. This research emphasizes the approach qualitativeevaluative, to explain the phenomena found in the field. This study found that mismanagement of village fund was not only caused by weak supervision and low human resources but also caused by the dominant, undemocratic and oligarchic aspects of leadership which had implications for the powerlessness of village actors in managing village funds in accordance with procedures, accountability, and transparency. Moreover, the formulation stage of the policy on the use of village funds is only a formality so that the power of the leader (the Village Head) cannot be implemented in the ethics of public administration and good governance.
\end{abstract}

\section{Keywords:}

Management; power of the village head; village administration.

\section{Introduction}

This research departs from the anxiety about the issue of village funds management in various regions in Indonesia which tends to be unaccountable. The policy of village funds itself which given to each village are to increase infrastructure development and empower the community towards a prosperous village. In addition, village funds are also intended to expand the functions and roles of the village governments, village management, improvement of services to the community, improvement and development of the rural economy as stipulated in Law Number 6 of 2014 concerning villages to strengthen their position within the framework of the Unitary State Republic of Indonesia. 
One of the policies that accompany the stipulation of Law Number 6 of 2014 is the village fund policy. Village funds, as explained in Government Regulation Number 60 of 2014 concerning village funds sourced from the APBN, are funds sourced from the State Budget $(\mathrm{APBN})$ which are intended for villages and transferred through the Regional Budget (APBD) of the regency/city and used to finance governance, development, community development and empowerment.

In managing village funds, the Government also prepares all its policy instruments, such as technical procedures for management from planning, utilization, distributing, supervising to reporting. This step is carried out through workshops that are managed by the government from the level above. The aim is that the village funds are in accordance with the interests of development and to avoid misuse that impacts on the legal bondage to the administrators.

There are limited findings in the field, for example, in utilizing village funds do not begin with a substantive formulation process, except for formalities so that the village needs do not reflect the needs and aspirations of villagers itself. However, the formulation process is a series of standard operation and technical procedures for managing village funds which is called planning. But at the planning stage, the participants in the village meetings tended to be co-opted by the strong authority of the Village Head who tended to be agreed by other village officials to the neighborhood association (RT) level as a representation of the residents in the village.

At the implementation stage, as the results of planning in the infrastructure development and community empowerment fields, it is not managed by engaging community resources potentials in the village such as self-management patterns, unless handed over to a third party. The weak empowerment of community resources in participatory village-based fund management is a surface issue that is covered in the introduction of this research. Furthermore, this is also suspected to be occurred to almost all villages in Indonesia, where the position of the Village Representative Body (BPD) is a "seal stamp" only.

Large expectations on the Village Laws with one of the policy tools which is in form of budgeted village funds and not in the context of merely purposing to develop villages only where the State is the main actor. But interpreted beyond as the village building, so that 
the village becomes strong independently. Robert Chamber (1987) outlooked if building a village means that the state is present in the front, as the main actor who builds a village, meanwhile village building means a village development that starts from behind. The state is positioned behind the village to encourage independence in self-development. Unfortunately, the expectation of village independence is always plagued by problems related to poor management of the village funds.

Research conducted by Sari and her colleagues (2017) on village funds management based on the perspective of community empowerment in Ngasem Village, Kediri, for example, only looks at the aspects of the procedural series from the planning stage, implementation stage, supervision stage, accountability stage and reporting stage. The conclusion in their research is that the stages were implemented poorly, and there were inhibiting factors in the form of synchronization between planning at the village and subdistrict levels, and the lack of intensity of socialization of the village fund to the community. While Putera, et al (2017), in the same focus relate to the stages and series of village fund management. It is just that in this research the use of the village fund is more likely to be allocated to the operational costs of the village government and BPD so that the use of the village fund budget is not in accordance with the allotment.

On the other hand, a research conducted by Kholmi (2016), looked at the management of the village fund in the public accountability approach as in the case of Kedungbetik Village, Jombang. According to him, in this village, the management of the village fund was accountable. The planning was based on program proposals from the village and evaluated through a village-level consultation forum. Then the accountability report on the implementation of the Village Fund is integrated with the accountability of the APBDesa (village income and expenditure budget). The obstacle in this research was the lack of understanding of the village apparatus in implementing their village fund.

As the findings concluded by Pramesti (2015), there are some interesting points to understand in seeing that the village fund management is not yet accountable. Pramesti states that the phenomena associated with the management of the village fund are (1) the accountability report made by the village that does not yet follow the standards and is prone to manipulation. And the village budget prepared does not fully reflect the needs of the village; (2) in the aspect of supervision there are three potential problems faced: low 
effectiveness of the regional inspectorate in supervising financial management in the village, unwell-managed channels for public complaints by all regions and the unclear scope of evaluation of supervision conducted by the head of the district; and (3) from the aspect of human resources there are potential problems which is corruption by utilizing the weakness of village officials.

Sari, Pramesti and Putera looked more at the administrative aspects of managing village funds in the context of development and empowerment goals. But neither of the have seen other aspects that might raise the question of the existence of village actors that could be potentially counterproductive to the management of village funds, or have implications for acts of corruption. Kadir, et al (2018) identified the tendency for the mode of irregularities in village fund management. Research that has moved from the aim of knowing the potential of corruption in managing village funds and to finding out efforts to prevent corruption in managing village funds, as a juridical study found that in terms of preventing corruption in managing village funds is trying to identify various modes of corruption in the village, increasing the capacity building of village officials and strengthening the capacity of village facilitators.

The general cases, as explained previously, are not much different from the reality of the initial allegations of village fund management in Jejangkit Pasar Village, Jejangkit District, Barito Kuala Regency of South Kalimantan. That the management of village funds is not in accordance with the expectations including; (1) the lack of transparency in the management of village funds, (2) lack of accountability in the process of planning of the use of the budget, (3) village deliberations are only formalities, (4) the choice of policies and development programs are not well targeted, (5) weak orientation of community empowerment, (6 ) weak managing and planning resources (7), the strengthened relations of conflict between citizens over the mismanagement of village funds, and (8) have implications for the weakening of community social capital. The eight points are problems that are suspected as mismanagement of village funds in Desa Jejangkit Market.

According to researchers, this has become an important issue in looking further at the management of village funds after the enactment of Law Number 6 of 2014. This research tries to get a bit out of the general approach that analyzes village fund management with institutional and functional approaches. But by using a policy evaluation approach and 
a perspective of inside and outside the village institution in a comprehensive manner towards the village fund policy.

This research also tries to reveal other aspects related to the management of village funds, both the relationship between the village head and other village officials, including his citizens. This research with a policy program evaluation approach tries to see how big is the gap between the achievements and expectations of a village fund management program policy for development and empowerment of the community, outputs, and outcomes, constraints, including the possibility of new findings. In an academic context, this research fills in the blanks of perspective from previous research.

Policy evaluation is an important stage in the public policy process. However, policy evaluation can be interpreted as an activity of evaluating policy products and/or interpreted as an examination of the process and series of activities of the policy program. Therefore, if the choice of understanding of policy evaluation is the last one, according to the researchers, what is needed is knowledge of policy analysis as a bridge in conducting policy evaluation.

Nagel in Tangkalisan (2003) provides the view that policy analysis is the best alternative to public policy that is able to provide a way out of various alternatives. Nagel emphasized that there are five main elements in evaluating policies from activating policy analysis: (a) the existence of objectives, including those related to normative constraints and relative considerations for achieving goals. In the perspective of evaluation will unravel what is planned and how targeted the achievement of policy objectives; (b) the existence of a set of policies as an effort to achieve goals such as decisions, programs and infrastructures; (c) there is a relationship between policies and objectives, institutions, facilities, authorities, estimations, and others; (d) the existence of tentative conclusions as a policy, and (e) determining what will be done to map alternative policies.

Merilyn in Winarno (2016) has a point of view that is interesting to be examined in dialectics on research related to policy evaluation. According to her evaluation plays a number of main functions in policy analysis. First, and the most important, evaluation provides valid and reliable information about the performance of the policy - how far the needs, values, opportunities, and goals that have been achieved through public action. Second, evaluation contributes to clarification and criticism of the values that underlie the selection of goals and targets. Third, evaluation contributes to the application of other policy 
analysis methods, including the formulation of problems and recommendations. Information about inadequate policy performance can contribute to the reformulation of policy issues.

Steps in conducting a policy, at least, must prioritize a number of indicators, so there is no wildness in conducting analysis as the main tool for policy evaluation. Edward A. Schuman in Winarno (2002) suggests six steps in policy evaluation: (1) identifying the program objectives to be evaluated; (2) analysis of the problem; (3) description and standardization of activities; (4) measurement of the level of change that occurs; (5) determining whether the observed changes are the result of the activity or due to other causes; and (6) several indicators to determine the existence of an impact.

Furthermore, the view of Nugroho (2012) is also interesting to be examined that there are four functions of policy evaluation. First, explanation - through evaluation the reality of program implementation can be portrayed and a generalization can be made of the patterns of relationships between the various dimensions of reality that are observed. Second, compliance - thorough evaluation can be seen whether the actions taken by the actors, both bureaucracy and other actors are in accordance with the standards and procedures set by the policy. Third, audit - thorough evaluation can be seen whether the output actually reaches the target group of the policy or there is a leak or deviation. Fifth, accounting - with an evaluation can be seen what the socio-economic consequences of the policy.

Effendi's view (2007) for example, the purpose of evaluating the implementation of public policies is to find variations in performance indicators that are used to answer three main questions: (1) how is the performance of public policy implementation? The answer concerns the performance of public implementation (variation of outcomes) on certain independent variables. (2) What factors cause the variation? The answer concerns the policy factors themselves, the organization of policy implementation, and the policy implementation environment that influences the outcome of policy implementation. (3) What is the output like? It depends on the process of formulation, its implementation and output as well as the factors and roles of other actors in all of these processes.

In research related to policy evaluation, shows that opinion of Shadish (1987) and Weiss (1984) in Tangkilisan (2003) that value-critics are rarely used in policy evaluation activities. This view confirms that normative information is very important in seeing the 
process of debate, discussion and argumentation processes that accompany the programming and decision making of the actors. Normative information is essential to understanding the value that is embedded in every social program. According to the authors, that this view tries to oppose the policy formulation process in which stakeholders are usually presented with choices made and the evaluator will only see decision choices as input with a series of outputs and outcomes in the evaluation notes. Including rationalizing the choice of policy makers on the back of an existence of feasibility namely effectiveness and efficiency.

Dunn (1981) also advocates this by stating that the existence of a value-critical evaluation component facilitates the transformation of information by clarifying the values and assumptions needed to provide reasons for debate and argumentation during the processes that surround policy decisions, specifically the role of actors surrounding the policy process.

In the old concepts, policy evaluation often relies on a series of inputs, output processes and outcomes which are then given an assessment (estimation). This is as a simple definition by Anderson (1975) as a public policy figure in the 20th century, saying that policy evaluation is an activity that involves estimation or policy evaluation that includes substance, implementation and impact. Policy evaluation is seen as a functional activity. This means that policy evaluation is not only carried out at the final stage but rather to the entire policy process. Furthermore, Dunn (1981), the term evaluation has a related meaning, each of which refers to the application of several value scales to the results of policies and programs. The evaluation includes conclusions, clarifications, criticisms, adjustments and formulation of the problem again.

The case of village fund management in Jejangkit Pasar village in this research was also dissected in a series as directed by Edward A. Schuman who elaborated the stages of formulation, implementation and policy outputs and outcomes, while providing space for the analysis of other variables that opened the door to novelty in this research in the form of the roles of the actors involved.

Furthermore, enrichment of management theory in the context of examining the management that rests on the basic processes and stages in management. Management of Village Fund in the perspective of public policy is generally included in the domain of 
public policy management. It means that the process of public policy as a management reality must be arranged on the basis of management principles. In general, the management principles that experts say consist of planning, actuating, organization and controlling (Terry, 1990). The paradigm shift in public administration from Old Public Administration (OPA), New Public Administration (NPA), then New Public Management (NPM), to the New Public Service (NPS) and finally New Public Governance (NPG), confirms the development of public administration emphasizing the strengthening management principles, especially those which are oriented to the aspects of effectiveness and efficiency.

In the context of village fund management researchers argue that it is very closely related to the NPM and NPG paradigm in which the NPM emphasizes management principles with an orientation to effectiveness and efficiency, while NPG emphasizes participatory principles and the role of actors in the policy set. The role of actors is interpreted as a synergistic relationship between government, society and the private sectors which is an important part of good governance. Thoha (2014) states that good governance encourages good governing management that guarantees a process of alignment, equality, cohesion, and balance of roles and the existence of mutual control carried out by all components. In this case, the series of management of village funds cannot release various variables such as participation, leadership, control, planning, formulation and aspects of the socio-cultural environment. This is the gap that is become one of the variables of this research relating to the relations and interactions of the actors in managing village funds.

The research on village fund management Jejangkit Pasar village will use elements of public policy management. Because this research avoids the confines of positivistic understanding that constructs studies from the very beginning without leaving room for new findings and trapped in the principles of mainstream management. The following will be illustrated how the research conceptual framework will be implemented:

Figure 1.

\section{Research Conceptual Framework (road map)}

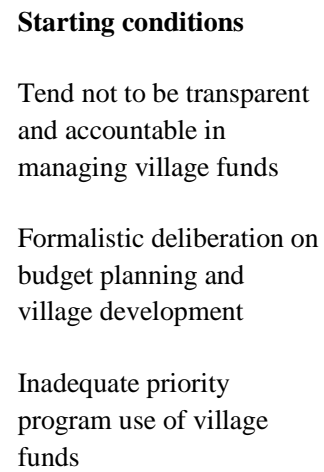

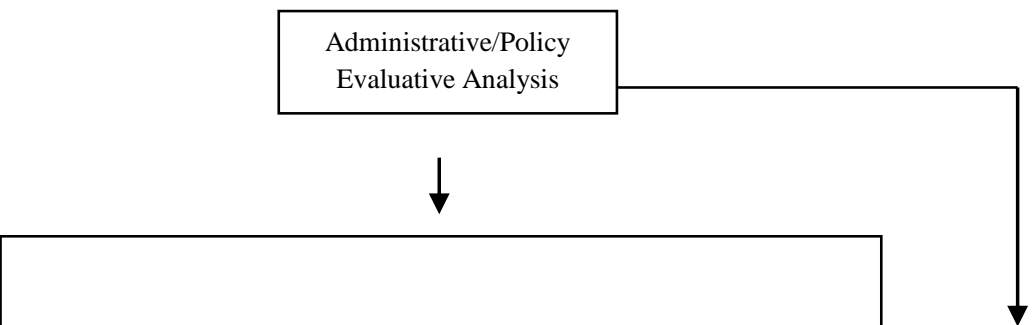

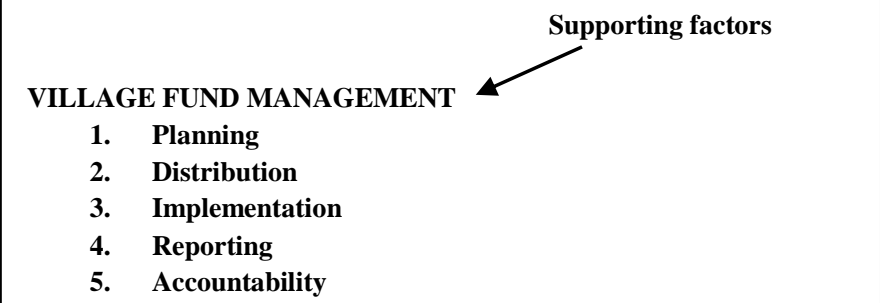




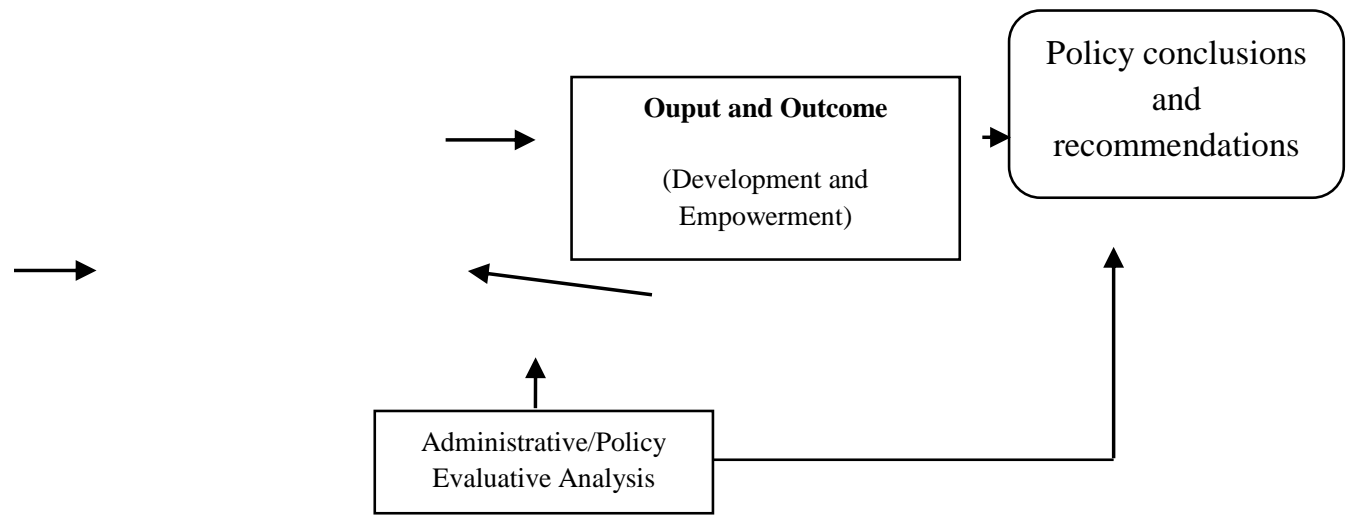

Source: Formulated by the researchers, 2018.

\section{Methods}

This research is a case study using a qualitative approach by avoiding positivistic thinking. Researchers answer the problem formulation with in-depth interview methods, conducting FGDs and participant observation combined with literature studies related to village fund management policies. The challenge of research with a policy evaluation perspective is to try to look deeply into the paths in the policy cycle and the stages in village fund management. For this reason, the data collected is continued by sorting and analyzing. The cross-check method is needed in every data obtained to be analyzed from the perspective of policy evaluation. Because allowing interview information tends to be biassed because it is very possible that actors in policy carry a variety of interests.

Flexibility in this research is still emphasized to explore new findings outside of the conceptual framework that was built. This research also emphasizes value-critics evaluation which means the debates and arguments behind the presence of decisions in the process of policy formulation and implementation of village fund management. Jejangkit Pasar village locus is based on raising issues related to improper management of village funds compared to neighboring villages. Therefore, this research is more focused on the construction of research of public policy which emphasizes scientific findings and recommendations, not on research for public policy.

\section{Results and Discussion}




\section{Mismanagement and the Power of the Village Head}

The existence of the Village Law Number 6 of 2014 which provides village funds makes villages in Indonesia like getting "collapses ripe durian". Even many who upgraded their status from village to village administered by a "Lurah" want to become a village again. Moreover, the village government is given the authority to manage the village funds for the benefit of development and community empowerment.

In addition to the two areas of authority, funding comes from other sources such as the Village Fund Allocation (ADD) sourced from the Regional Budget and Revenue (APBD), revenue sharing from local taxes and levies as well as the village's original income. Village priorities, activities and budgets are agreed upon in participatory village meetings. The results of the village deliberations became the reference in the Village Government Work Plan (RKPDesa) and the Village Budget (APBDesa).

The community of Jejangkit Pasar village when this research was conducted responded that village funds such as a windfall for the Village Head and village government officials. The community of Jejangkit Pasar village assessed and tracked several cases in the management of village funds that were relatively closed and only formalistic to the community, including reports to the district and regency supervisors. An easy reason for the community to provide an assessment of village fund management is by comparing to neighboring villages namely Jejangkit Muara village which also has the same relative disbursement of funds from the state budget and regional budget of Barito Kuala district. But the management is done well, transparent and has evidence of infrastructure development and community empowerment.

The findings of this research state that there are numbers of program activities that have been prepared and implemented, but many have not yet been completed or have not even been completed. Moreover, the Regency Government will not disburse funds if there are plans and implementations that have not been completed. This fact encourages residents through the Sector Police Chief and Village Development Guards to encourage village meetings in order to encourage the Village Head to carry out his duties in a trustful, transparent and responsible manner. Aside from that, only the construction of the village maternity center is under construction throughout the study carried out in late November 2018. 
"How it can be implemented, some of the programs and projects specified in the village regulations if in reality the previous programs have not been completed. The Regency Government will disburse if the work completed followed by the accountability report". (Interview with Village Figure, Jejangkit Pasar, November $12^{\text {th }}, 2018$ )

\section{Figure 2.}

Budget for the Implementation of Village Development in 2018

\begin{tabular}{|l|l|l|l|}
\hline \multicolumn{1}{|c|}{ No. } & \multicolumn{1}{|c|}{ Development Implementation } & \multicolumn{1}{c|}{ Budget } & \multicolumn{1}{c|}{ Explanation } \\
\hline $\mathbf{1 .}$ & $\begin{array}{l}\text { Construction and maintenance of } \\
\text { environmental roads }\end{array}$ & $\operatorname{Rp} 57.353 .000$ & $\begin{array}{l}\text { Completed, invite questions of } \\
\text { budget value }\end{array}$ \\
\hline $\mathbf{2 .}$ & $\begin{array}{l}\text { Construction and maintenance of } \\
\text { farming roads }\end{array}$ & $\operatorname{Rp~273.311.000}$ & $\begin{array}{l}\text { Incomplete, invite questions of } \\
\text { budget value }\end{array}$ \\
\hline $\mathbf{3 .}$ & $\begin{array}{l}\text { Construction and maintenance of } \\
\text { bridges }\end{array}$ & $\operatorname{Rp~27.167.831}$ & not yet implemented \\
\hline $\mathbf{4 .}$ & Well's culverts & $\operatorname{Rp~14.280.000}$ & not yet implemented \\
\hline $\mathbf{5 .}$ & $\begin{array}{l}\text { Construction of the village } \\
\text { maternity center }\end{array}$ & $\operatorname{Rp~260.000.000}$ & $\begin{array}{l}\text { Incomplete }- \text { as the result of } \\
\text { residents' insistence that involved } \\
\text { the police }\end{array}$ \\
\hline
\end{tabular}

Source: Village's data and researcher's formulated data, December 2018.

The funds available from the State Budget and Regional Budget of Barito Kuala Regency are considered quite riveting for the villagers. However, budget management which is related to the area of community development and community empowerment, actually becomes a question for villagers, where is it used and when to use it? Even the villagers are questioning the use of the budget in the field of infrastructure development that is not yet complete. Whereas the neighboring villages every year have been able to complete the village head office with a permanent type with a large office yard and its contents.

The stages of village fund management as the findings of this research give a formalistic impression. All procedures and mechanisms have been carried out properly in accordance with existing provisions.

At the planning stage, Jejangkit Pasar village's government in the context of the village development meeting (Musrenbangdes) for example, follows the grooves and principles as stipulated in the Central Government Regulation - Minister of Domestic Affairs Regulation Number 114 of 2014 concerning Guidelines for Village Development. 
In the research findings in Desa Jejangkit Market, as the informant said, the village development meeting (Musrenbang) 2018 was held last January followed by the preparation of the Village RKP (Government Work Plan). The Village RKP is used as material for submitting disbursement of village funds to the Regency Government. The RKP is arranged based on need followed by the amount of the budget.

Nevertheless, the village development meeting was not exhaustive and unclear what is planned, especially the Village RKP which contains programs and projects for infrastructure development and community empowerment. The village development forum changes to mere formalistic participation, while the determination of the Village RKP in the appendices and composition changes without involving the BPD anymore but is carried out by village officials according to the wishes of the Village Head. The difference in the contents of the village development meeting results with what is stated in the Village Planning is a question mark for BPD and the community who propose planning through the neighborhood association (RT), and/or parties who know the differences in content from what has been agreed. Not a few people were shocked about the sudden development because form the principle of necessity aspect the community did not need it regarding there were still more important needs. For example, the provision of culverts for the wells' construction, although they have not been implemented because the funds were hampered.

Inputs from BPD and community leaders involved regarding the plan for the use and management of village funds during the village deliberations were not without consideration. Because most of the figures and BPD involved were former village heads, former village officials, and those who understood the needs and aspirations of the local people in Jejangkit Pasar village. The understanding of BPD members and this figure became a turmoil and criticism of the leadership steps of the Village Head. Moreover, in the view of the community, knowing there is a meeting or deliberation, only the involvement of meetings is very limited. There is even the impression that they are critically not involved. They only know of BPD members who are critical and express their dissatisfaction when talking in stalls or in public spaces.

"We simply compare how other villages really involve the community, and the role of BPD members. What was gathered together was in accordance with the RKP and even in other 
villages there was a large billboard on the side of the road with clear pictures and text. This in the Market Trail does not include the stages at what percentage is realized. We are jealous of the neighboring village". (Informant interview, November 2018)

At the stage of distribution of village funds, as stipulated in the Law. Distribution of village funds is carried out by way of book-transfer from the State General Cash Account abbreviated as RKUN to the Regional General Cash Account abbreviated as RKUD. Research findings suggest that at the initial stage the $40 \%$ disbursement of funds based on planning documents (Village RKP) did not proceed as expected. The funding factor that has stagnated from the treasurer due to the intervention of the Village Head in "lending funds for personal needs" interferes with the use of Village RKP funds in accordance with their designation. This fact results in the impact of project development and subsequent development and empowerment activities. For example, the construction of a village maternity center that was urged by the residents and the BPD finally began work in November 2018, including several environmental roads and farming, which should have been carried out during the disbursement of the first phase in April 2018.

The condition of the management of the use of village funds like this for the community of Jejangkit Pasar village is feared to give birth to jobs that are made carelessly and only based on administrative reporting with low quality and accountability of the contents of the doubtful reporting. The fact is that the work on infrastructure projects has been struggling. It even raises suspicions, doubts about the number or specs of projects that are not in accordance with plans and field evidence, and ignores community empowerment and self-management, such as environmental road works, culvert well plans, and community empowerment activities.

As stated by the informant, the process and mechanism for channeling funds are in accordance with the provisions. The regency government will distribute it if the conditions have met, both at the initial and subsequent stages of distribution. There is no obstacle for Jejangkit Pasar Village, because it meets the requirements such as having a village account and banking service coverage that can be used at any time, the Batola District Regulation that facilitates the distribution of Village Funds required by Perdes, RKPDes and APBDes. 
The fact that the distribution of village funds in Jejangkit Pasar has fulfilled the requirements so that they can be disbursed directly to the village account. The research findings state that when submitting a proposal for the disbursement of funds to the Barito Kuala Regency Government, the village head with the treasurer brought SPP (Request for Request for Long-Term) issued by the head of the village finance urure (Kaur). The village finance bureau issues SPP based on the request of the village head known by the BPD Desa Jejangkit Pasar element. After receiving SPP, the funds are transferred by the regency government to the village account which can only be disbursed with the signature of the village head and treasurer.

"So the channeling funds from the regency government have no problem, as long as it fulfills requirements such as the completion of work and the existence of accountability reports. Unfortunately, many are incomplete because they are stalled due to the money being used privately without meeting with the Village Government of Jejangkit Market itself."(Interview informant, 21 November 2018)

At the implementation stage, mismanagement from the planning and distribution stages impact mismanagement at the implementation stage. Coordination and direction among village elites (village heads, BPD members and village officials) do not reflect good management. Even worse, the sustainability of the activity continues because it prioritizes the formality of reports and evidence. While the quality of management is not as expected as stipulated in the Village Law and Village Minister's Regulation Number 5 of 2015 concerning priorities of the use of village funds. This research found, for example, that after the village development meeting and RKP, which had "changed unilaterally", had progressed to the level of implementation. For example, the construction of the village maternity center that had been planned in the early year, but in November 2018 it was only built by handing over the implementation to third parties outside the residents of Jejangkit Pasar village. Whereas the public expected to do by themselves, it is whether the villagers are individuals or groups so that new jobs are distributed to residents according to conditions, abilities, and agreements or with selfmanagement patterns. The research team interviewed workers (Jejangkit Pasar residence) that they got a job from a contractor who lived in Banjarmasin with a piece rate of Rp. 30,000,000 (thirty million rupiah) from the construction of the foundation to 
the painting. The total work of the village maternity center as stated in the RKP is Rp.260,000,000 (two hundred sixty million rupiah). The source of reporting data as mentioned above, dated April 30th, 2018, provides an illustration of the realization of the more dominant budget used in the field of governance that has not touched the interests of the public needs.

So far, the village head has never involved village officials or even BPD members in determining who will work on infrastructure projects. Whereas, he hopes, it can be done in a self-managed manner by involving villagers as workers so that they can get additional income. All such implementation matters are carried out by the village head alone. The head of financial and treasurer affairs is only cross-funding, "stamp seal" formalities and signatures. This fact also applies to the head of development and general affairs, where he only receives documents and signs the activities as the Committee for Recipient of Activities (PHK) from the Activity Implementation Team (TPK) whose position is as a formality. These formality documents have been the basis for the Regency Government to disburse funds at a later stage if they are deemed complete and meet the requirements.

The village apparatus related to the signing of the document was forced to sign, because they considered the conditions and documents to be complete, as was the procedure. But the role and function as mandated by the Law and Ministerial Regulation was ignored. The gaps in management irregularities are already very visible in the process of managing village funds in Jejangkit Pasar, due to the formality mode and one-sided budget control by the village head and the silence of other village officials.

At the reporting and accountability stage, it is known that this process and mechanism are followed by document, official records, and neat reporting and seem to get a good response from the community. However, the reality of document and official records in the accountability report does not imply public participation, accountability, and transparency. The evaluative analysis in this research states that the value of the budget issued from the Village RKP actually absorbs more in the field of government administration, but not in development and community empowerment. This document is analyzed from the accountability reports as of April, August, and December, which 
almost neglected the realization of the field of community empowerment, and the conditions of scheduling in the field of infrastructure development are not appropriate.

As the research findings showed, the community of the village and BPD leaders had submitted a report on the irregularities in the management of Jejangkit Pasar to the district and regency authorities. However, it seems that the response of district and regency government institutions is only based on accountability reports, especially the formalistic use of finance, without cross-checking the effectiveness of village fund management. This is what causes the protest movement and oversight of citizens and BPD members are vulnerable to weakening and can even be said to stagger, apathy and indifference. ${ }^{1}$ Where the supervisors only rely on evidence of infrastructure and administrative reports, even though there are gaps in the lateness it is actually possible to explore the problem of what happened as the supervisor and the village supervisor.

"We often remind and even convey to the districts and regencies to foster and participate in overcoming the problems encountered. However, it seems that they only holding on to the written reports without examining several RKPs that were not realized and also did not find out the cause." (Informant Interview, December 2nd, 2018).

\section{Village Administration Dilemma}

The administrative conditions in the village of Jejangkit Market which received the attention of residents. Government officials confirmed that there were many shortcomings in the implementation and management of village funds, but on the other hand, they also thought of loyalty to the leadership and maintaining the stability of the administration of village government. The findings of this study, for example, gained the fact that village officials were sometimes "forced" to sign documents in the context of

1 There was an assumption, that the inability of villagers to protest to the district and tended to be neglected, seemed to position the Village Head as a "strong" family of the Barito Kuala Regent. Even the election victory is considered as a "payment" for the unquestioned of mismanagement of village funds' allocation of the Jejangkit Pasar village Government. For some villagers, the Regent's victory was due to the strong success of the Golkar Party's branch and the kindness of Mr. Hasanuddin Murad so far for the residents of Jejangkit Pasar, including Mrs. Normaliyani who always accompanied Mr. Hasanuddin Murad. 
submitting funds to the district government, even though they felt the proposals contained in the RKP were less reflective of the interests of development and community empowerment.

In this context, residents finally suspect that the village head always avoids meeting with the community and village officials in a forum because they will ask about the performance and responsibilities in village government administration. This fact also finally justifies the community's allegations about irregularities in the management of village funds as explained earlier in the findings of this study. This fact also triggered villagers to urge the construction of a village maternity center and other programs as stipulated in the village Market Survey RKP. The community is concerned that poor management of the Village Fund will give them sanctions from the district government, only because of the lack of seriousness of the village head in leading the village. Instead of thinking about other programs that are more pro-effective such as increasing village investment, cooperation between villages and outsiders, developing BUMDes (villageowned enterprises), organizing communities, making rural tourism, developing village spatial planning for settlements and plantations including community development. village youth and community.

As the research findings show, this process and mechanism are followed by neat documents and reporting that seem to get a good response from the community. However, the reality of documents, data in the accountability reporting file does not imply public participation, accountability and transparency. Evaluative analysis in this research states that the value of the budget issued from the village RKP actually absorbed more in the field of government administration, not in community development and empowerment. This document is analyzed from the accountability reports for April, August and December, which almost neglected the realization of the field of community empowerment, and the scheduling conditions for the construction (infrastructure) are not appropriate.

Such conditions gave birth to ripples of protest from residents, especially members of the BPD Jejangkit Pasar and community leaders. However, the report according to the procedure and mechanism caused ripples of protest from the people of Jejangkit Pasar as if scattered. The material for the community protest was enough to see a comparison 
with neighboring villages such as Jejangkit Muara and Jejangkit Timur which were more progressive, proven to have an output and output, increased citizen participation and transparency.

"We often remind and even convey to the districts and regencies to foster and participate in overcoming the problems encountered. However, it seems that they only moved to written reports without examining several RKPS that were not realized and were not found out why." (Informant Interview, December 2018).

\section{Conclusion}

Compared to the research so far which examined the management of funds in the aspects of the stages as required in Law Number 6 of 2014 concerning villages and also the Minister of Village Regulation, Development of Disadvantaged Regions and Transmigration Number 2 of 2015 concerning guidelines for standing orders for the mechanism of decision on village deliberations, as well as Village Minister Regulation, Underdeveloped Regional Development and Transmigration Number 4 of 2015 regarding establishment, arrangement, management, and dissolution of BUMDes. Research with a case study of evaluating the management of the village fund in Jejangkit Pasar village is based on questioning the management and policy of the village fund behind these stages theoretically and practically outside of previous research relating to the same topic.

The main criticism in this research on the application of management theory is that there are deviations from all levels of the management process that emphasizes the formality of counterproductive behavior in leadership and management. The gaps in the policy process, such as in the planning stage, are examined by the policy cycle, which is the formulation of policy that is very far from the expectations of the theory that leads to discourse, debatable and participatory. That the power of the leader (Village Head) has denied the ethics of public administration and good governance in the form of transparency and responsibility for the mastery of the budget that should be managed fully administratively by the Village Treasurer.

The case of Village Fund Management in Jejangkit is an interesting function and role of supervision and supervisors of the government above it and is not included in the formalistic trap in examining administrative reporting, but exploring gaps that allow for an 
evaluation of improved financial management and activities. The construction of good governance is expected to be participatory, transparent and accountable. Because the New Public Governance with the principles of good public governance encourages a conception of governance which is clean, democratic and effective that also regulates the relationship between government, the private sector, and the community. The implementation of good governance (GPG) is inseparable from the application of government management systems from a series of planning, organizing, actuating and controlling that are done professionally and consistently.

Furthermore, the reality so far is that the formality aspect is too resting on the Government to account for activities at all levels. Ability to supervise as the principles of management and evaluation of the process of formulation and implementation of policies has not found the will of the theory and the mandate of regulation/policy. The main point of this research is that the management of village fund management is dominant in the transparency process. As Smith suggested (2004: 66) at least the fulfillment of the process is: (1) Standard procedural requierement, (2) Consultation processes, (3) Appeal right to avoid corrupt practices.

As a result, the formality mask from the level of the Village Government to the Government above it enriched the systematic manipulative and corrupt practices of the village government. BPD members and citizens who become agents of supervision and participation, are actually attacked by a virus of ignorance that is increasingly weaker the power of knowledge/information on budget management, weak criticism and weak alertness. This reality can finally be concluded that the presence of the Village Fund and Village Fund Allocation policies are not a blessing in the context of building independence and empowerment and community welfare, but rather are triggering the weakening of social capital that has been well maintained in the community.

\section{References}

Anderson, G. (1984). Rationality in Science and Politics. Dordrect, Holland: D.Reidel.

Denhardrt, B. Robert \& Janet V Denhardrt. (2006). Public Administration: An Action

Orientation. Fifth Edition. USA: Thomson Wadsworth, a part of The Thomson Corporation. 
Dunn, William N. (1981). Public Policy Analysis: An Introduction. Englewood Cliffs, NJ: Prentice-Hail.

Kadir, etc. (2018). Pencegahan Korupsi Dalam Pengelolaan Dana Desa. Jurnal IUS, 6(3), EISSN: 2477-815X, P-ISSN: 2303-3827.

Kholmi, Masiyah. (2016). Akuntabilitas Pengelolaan Alokasi Dana Desa: Studi di Desa Kedungbetik, Jombang. E-jurnal Ekonomika-Bisnis, 7(2), 143-152.

Nugroho, Riant \& Wrihatnolo, Randy. (2012). Manajemen Perencanaan Pembangunan. Jakarta: PT Alex Media Komputindo.

Pramesti, Firda Ay, etc. (2018). Akuntabilitas Pengelolaan Dana Desa di Desa Temulus Kecamatan Bejubu Kabupaten Kudus. Journal of Politic and Government Studies, 2(2).

Putera, Kusuma Chandra. (2017). Pengelolaan Alokasi Dana Desa Dalam Pemberdayaan Masyarakat Desa. Kasus Desa Wonorejo, Malang. E-journal Jurnal Administrasi Publik, FIA UB, 3(11), 1203-1212.

Sari, N.Risya, etc. (2017). Pengelolaan Dana Alokasi Desa Dalam Perspektif Pemberdayaan Masyarakat. Kasus Desa Ngasem, Kediri. E-journal Jurnal Administrasi Publik, FIA UB, 3(11), 1880-1885.

Smith, Rex Deighton. (2004). Regulatory Transparency in OECD Countries: Overview. Trends Challenges. Australia: Journal of Public Administration.

Tangkilisan, Hessel Nogi S. (2003). Evaluasi Kebijakan Publik. Yogyakarta: UGM Press.

Terry, George, etc. (2013). Dasar-Dasar Managemen. Jakarta: Bumi Aksara.

Thoha, Miftah. (2014). Ilmu Administrasi Publik Kontemporer. Jakarta: Kencana Prenadamedia Group.

Wilson, E.G. (1980). The National Planning Idea in Public Policy. Westview: Boulder, Co.

Winarno, Budi. (2002). Kebijakan Publik: Teori, Proses, dan Studi Kasus. Yogyakarta: CAPS.

\section{Documents}

Peraturan Menteri Dalam Negeri No.37 Tahun 2007 Pedoman Pengelolaan Keuangan Desa.

Peraturan Pemerintah Republik Indonesia Nomor 72 Tahun 2005 Tentang Desa.

Undang-Undang Nomor 23 Tahun 2014 Tentang Pemerintah Daerah.

Undang-Undang Nomor 6 Tahun 2014 Tentang Desa. 
Peraturan Menteri Desa, Pembangunan Daerah Tertinggal dan Transmigrasi Nomor 2 Tahun 2015 Tentang Pedoman Tata Tertib Mekanisme Pengambilan Keputusan Musyawarah Desa. 